\title{
Australian Military Nursing from ANZAC to Now: Embracing the Ghosts of Our Nursing Ancestors
}

\author{
Narelle Biedermann \\ Nursing, Midwifery and Nutrition, College of Healthcare Sciences, James Cook University, Townsville, Australia \\ Email: narelle.biedermann@jcu.edu.au
}

How to cite this paper: Biedermann, N. (2017). Australian Military Nursing from ANZAC to Now: Embracing the Ghosts of Our Nursing Ancestors. Advances in Historical Studies, 6, 65-77. https://doi.org/10.4236/ahs.2017.62005

Received: February 15, 2017

Accepted: June 17, 2017

Published: June 21, 2017

Copyright $\odot 2017$ by author and Scientific Research Publishing Inc. This work is licensed under the Creative Commons Attribution International License (CC BY 4.0).

http://creativecommons.org/licenses/by/4.0/ (c) (i) Open Access

\begin{abstract}
Britain declared war on Germany on 4 August 1914. The following day, Australia was also formally at war. Australian nurses were quick to volunteer to support Australia's war effort, and what was to follow for these women was unprecedented up until that time-professionally and personally. War and nursing are historically linked; where there is war, there is death, injury and illness, and where there is suffering, there are nurses and carers determined to alleviate that suffering. The fact that there are Australian military nurses serving overseas right now validates this. The purpose of this paper is to explore Australian military nursing from the contexts of World War 1 and contemporary military operations. At this time when commemorations to mark the centenary of Australia's involvement in World War 1 are ever most present around the nation, encouraging us to reflect upon and learn more about Australia's military history, it is important that this comparison occurs as a means of reinforcing the significance of the contribution made by our nursing ancestors and acknowledge their influence on the practice of military nurses today. An analysis of practice between the two eras highlights that whilst there are obvious differences, there are some important parallels that have implications for both the military and civilian nursing profession.
\end{abstract}

\section{Keywords}

Australian Nursing History, Military Nursing History, War Nursing, Military Nursing

\section{Introduction}

Sometimes, the significance of what we do today will not be truly apparent unless it is seen against the backdrop of yesterday. The purpose of this paper is to 
explore military nursing care from ANZAC to contemporary practice to consider the ways in which care and rehabilitation of soldiers have evolved-and, perhaps, remained the same. These pioneering women-our nursing ancestors if you will-forged a direction for the care and rehabilitation of sick and injured soldiers that was based on what we now understand as evidence based practice. According to Harris (2011), the treatment of fever and shock was almost solely the realm of nurses, because they developed such intensive practices that often led to the recovery of many soldiers who might otherwise have succumbed to their illness. Much of what the general population accepts about nurses from World War 1 (WW1) and glamorized in the popular media centers on the ministering angel at the bedside, providing soldiers with a touch of the humane world of family and home. In other words, whilst the act of war is masculine, the presence of women on or near the battlefield serves to remind the warfighter what they are fighting for. Notwithstanding this may have been the case for some of the sick and wounded, when we delve into the nature of work undertaken by Australian military nurses in any war or conflict (Biedermann, 2001, 2004; Fleming, 2010; Fletcher, 2011; McCullagh, 2010), we quickly see that their role was and is much more profound and significant than that. In order to appreciate this significance, it is important that we understand the contexts of military nursing over time.

\section{Historical Context of Military Nursing}

When WW1 broke out in 1914, the Australian Army Nursing Service (AANS) was not yet in its teens. Functioning in a purely reserve capacity, the AANS comprised of part-time, volunteer civilian nurses. Its sole purpose upon establishment was to provide "trained and efficient nurses (who will be) available for duty at the Base Hospitals and Stationary Field Hospitals in times of national emergency" (Bassett, 1992: p. 26). In order to be eligible for the new service, the candidates had to be female, aged between twenty-one and forty, and have a minimum of three years' nursing experience from a recognized civilian hospital. Once accepted into the service, efficiency was determined annually by first aid tests and attendance at lectures on such topics as the organization of the military hospital, army regulations, hygiene, prevention and nursing of tropical diseases, and military surgery.

After the outbreak of war, the AANS was inundated with volunteers of trained nurses, with more than 300 nurses volunteering to serve by October 1914 (Harris, 2011). Twenty-five members of the AANS were part of the first convoy of the Australian Imperial Force (AIF) to sail from Albany in early November 1914, distributed among the seven ships that formed the convoy. Once at sea, their work began almost immediately, ranging from assisting in immunization parades and both major and minor operations, through to nursing an outbreak of measles amongst the troops. According to Goodman (1988), the deployment of these nurses was a mere political gesture, as at that stage, the construct of the force and how it would be employed had not been fully considered. Before the 
voyage was over, Turkey had declared war on the British and the convoy was diverted to Egypt. The nurses now had a role to play.

On 5 December 1914, an additional 161 nurses were on their way to Egypt to form the staff of No. 1 and No. 2 Australian General Hospital (Barker, 1989), and again, their work began as they put to sea, nursing troops sick with influenza and pneumonia on the outward journey (Goodman 1988; Harris, 2009a). By the end of 1916, more than 1300 Australian nurses were on active service overseas, with close to 700 remaining in Australia to staff military hospitals. The impact that this eager exodus of trained nurses, especially those with theatre experience, to overseas service and the redirection of medical supplies was felt heavily by many civilian hospitals, with profound shortages of staff, drugs, and dressings (Harris, 2014). Nevertheless, with nothing more than their nursing experience, enthusiasm, and a "higher calling" driving many of them (Butler, 2006), these women soon found themselves involved in harsh reality of war.

Throughout the duration of WW1, an estimated 2286 members of the AANS served overseas (Harris, 2008). They nursed on land in large general and auxiliary hospitals, and tented casualty clearing stations in a variety of places including New Guinea, Egypt, India, Salonica, Lemnos Island, France, Malta, Palestine, Mesopotamia, Northern Greece, Italy, Belgium, Russia and England, and worked at sea on board hospital ships, transports, and troop transport ships. Indeed, the majority of AANS spent time nursing at sea at some stage (Harris, 2009a). The Australian medical service provided three stages of treatment in which nurses worked to support land operations. The first stage was the casualty clearing station (CCS), which was a temporary system of tents located near the front line. Its purpose was to provide emergency treatment-to save life or limb-before transferring the patient further back for more sustained medical treatment. The hospital troop ships stationed off shore served the same purpose but in an amphibious capacity. The second stage of health care was received at the Australian General Hospital (AGH), which was usually better staffed to provide more sustained and prolonged treatment. The AGH were considered temporary and mobile, as it needed to remain in the vicinity of the campaigns as it moved to enable timely receipt of casualties. The final stage of treatment that nurses were involved in was the Australian Auxiliary Hospital (AAH). The purpose of this facility was to provide convalescence to patients requiring more extensive recovery. The overall aim of each of these treatment facilities was to return to the soldier back to the war. Soldiers who required longer recovery or convalescence (greater than six months), were usually returned to Australia and nursed in Australian military hospitals (Goodman, 1988).

It is worth noting that, although soldiers stopped fighting with the signing of the Armistice, nursing work continued. They remained nursing soldiers still recovering from their wounds and illnesses in military hospitals abroad and on hospital and transport ships returning to Australia, and were especially important in managing the Spanish flu epidemic sweeping the world (Harris, 2009b). Indeed, it wasn't until 1920 that the last of the majority of AANS nurses were 
demobilized.

\section{Contemporary Context of Military Nursing}

From the early 1990s, Australian military nurses increasingly became involved in support of military operations with deployments to the Persian Gulf and in support of United Nations and humanitarian operations, including deployments to Cambodia, Kurdistan, Somalia, Rwanda, Bougainville, East Timor, Solomon Islands, Banda Aceh, and Pakistan. More recently, military nurses have supported Australian forces involved in combat operations in Iraq and Afghanistan. For a more detailed summary of these operations, see Table 1. The purpose of having military nurses present on these operations was two-fold: firstly and most traditionally, to provide health support to the deployed force, and secondly, to provide health support to the community into which they deployed (Wright, 2002a).

\section{Comparisons}

It is understandable to believe that there are no similarities between the experiences of those pioneering women of the AANS in WW1 and those of the contemporary men and women who serve as military nurses now, a century later. At

Table 1. Contemporary operations involving ADF nurses.

\begin{tabular}{|c|c|c|}
\hline Location & Period & Operation \\
\hline Persian Gulf ${ }^{1}$ & $1990-1991$ & US-led Operation DESERT STORM \\
\hline Cambodia $^{2}$ & 1991-1993 & Operation GOODWILL, Operation GEMINI \\
\hline Kurdistan ${ }^{3}$ & 1991 & Operation HABITAT \\
\hline Somalia $^{2}$ & $1992-1993$ & Operation SOLACE \\
\hline Rwanda $^{2}$ & $1993-1994$ & Operation TAMAR \\
\hline Bougainville $^{3}$ & $1997-2003$ & Operation BEL ISI \\
\hline East Timor ${ }^{1}$ & $1999-2003$ & $\begin{array}{c}\text { Operation WARDEN, Operation TANAGER, } \\
\text { Operation CITADEL }\end{array}$ \\
\hline Solomon Islands ${ }^{2,3}$ & 2003-2005 & Operation ANODE \\
\hline Banda Aceh ${ }^{3}$ & 2005 & Operation SUMATRA ASSIST \\
\hline $\operatorname{Iraq}^{1}$ & 2005 & Operation CATALYST \\
\hline Pakistan $^{3}$ & 2006 & Operation PAKISTAN ASSIST \\
\hline $\mathrm{Fiji}^{3}$ & 2006 & Operation QUICKSTEP \\
\hline East Timor ${ }^{1}$ & $2006-2013$ & Operation ASTUTE \\
\hline Persian Gulf ${ }^{1}$ & $2003-2009$ & Operation SLIPPER \\
\hline Afghanistan $^{1}$ & 2001-current & $\begin{array}{c}\text { Operation SLIPPER, Operation HIGHROAD, } \\
\text { Operation PALATE II }\end{array}$ \\
\hline Ukraine $^{3}$ & 2014 & Operation HARWICK \\
\hline Bougainville $^{3}$ & 2014 & Operation RENDER SAFE \\
\hline $\operatorname{Iraq}^{1}$ & 2015-current & Operation OKRA \\
\hline $\mathrm{Fiji}^{3}$ & 2016 & Operation FIJI ASSIST \\
\hline
\end{tabular}

${ }^{1}$ Combat operation, ${ }^{2}$ Peacekeeping operation, ${ }^{3}$ Humanitarian operation. 
face value, the distinctions seem quite obvious. The employment of unmarried women at the beginning of last century differs from the current employment of both genders with no limitations placed upon them insofar as marital status or sexual preference. Contemporary military nurses are trained and proficient in the use of personal weapons to protect themselves and their patients; their ancestors were quite without protection apart from that provided by soldiers around them. The traditional and impractical nursing uniforms of the 1900s has long since been replaced by a uniform that sees the nurse assume the same identity as those around them. Technological and medical advancements see vastly different military medicine practices today, just as technological advancements in military weaponry and tactics have seen a massive change from the chaos and carnage of the battlefields of WW1. We still have weapons that kill and maim, and soldiers still get sick and succumb to illness, but the scale of warfare has significantly reduced.

However, there are some very significant parallels between the two eras in military nursing and for the purpose of this paper, these have been categorized into six themes: advanced practice, conditions faced, making a difference, caught in the crossfire, kinship and military family, and homecoming and adjustments. The following section will discuss these six themes.

\subsection{Advanced Practice}

The ramifications of war-injury, illness and death-has had an impact on the scope of practice of nurses throughout time. Advanced clinical practice in the military has often been forced by necessity. In the absence of enough doctors, surgeons, and anesthetists to cope with mass casualties, for example, military nurses have stepped up to take on advanced roles normally performed by doctors. In WW1, six AANS nurses were trained as anesthetists. One nurse commented whilst training: "I have given 179 anesthetics and no casualties so far. Although this work occupies about 12 hours at least of each day we are by no means cut off from our other work" (Bassett, 1992). Unfortunately, the Director General Medical Services of the AIF refused to sanction the employment of these trained nurses, and stopped them officially practicing (Harris, 2013). Other skills that nurses quickly became adept at handling was triage, artificial respiration, radiography, pain management, and skin grafting (Harris, 2011). There were even examples of nurses in CCS being asked to pick up a scalpel to operate on minor conditions, like the removal of foreign bodies (shrapnel, bullets) and cleaning up minor wounds (debriding wounds was a new practice in 1917), so that the surgeons could concentrate on the more serious wounds (Harris, 2011).

In Rwanda, nurses frequently assumed an expanded role in resuscitation, and in some cases, "it was necessary to run a resuscitation without a [doctor]. Here the role of the [nurse] expanded" (Harding, 2010: p. 328). During humanitarian operations, nurses generally work in independent roles in providing primary health care and advanced life support (Wright, 2002b). Additionally, the ADF has introduced nurse practitioners in areas like mental health (Ashley, 2003), 
emergency, and primary health care (O’Neill \& Luther, 2013) allowing independent advanced practice.

\subsection{Conditions Faced}

An obvious parallel between the two eras is the conditions under which the nurses worked and lived. Part of the ethos that military personnel accept is that during training and operations, they will sacrifice the normal comforts afforded to the rest of the population. Perhaps this mentality is best summarized by a sign displayed at the entrance of a military training center in tropical Queensland: "The oath to serve your country did not include a contract for normal luxury and comforts enjoyed within our society. On the contrary, it implied hardships, loyalty and devotion to duty, regardless of your rank" (Ashley, 2013: p. 203). In both periods, the conditions under which the nurses worked and lived ranged from primitive and unconventional (such as an amusement park, roller skating rink, French villas, schools, hotels, airfields, abandoned buildings) through to relatively comfortable and modern (considering the circumstances). One of the key differences unique to military health care professionals who are deployed on operations is that they can't go home at the end of their shift for there is no "home" to go to. Rather, "home" might be a tent three rows away from the ward, a "hutchie" adjacent to the facility, or a temporary hut attached to the makeshift hospital. There are occasions where "home" was on the floor next to their patients (Siers, 2013). In essence, the conditions under which they work are often similar to those in which they live.

According to Rees (2008), the conditions at the No. 3 AGH located on Lemnos were the worst experienced by any nurses during WW1. When the nurses first arrived in early August 1915, the "hospital" did not exist beyond casualties lying on the bare, rocky ground. It would be another few weeks before equipment with which to furnish the hospital would arrive. "Our patients were nursed on the ground in the open and it was on this ground that we slept. How we longed for a hole for our hips" (Rae, 2004). When tents to construct the hospital did arrive, they were terribly inadequate to deal with the environment and climate, regularly collapsing in the ferocious winds that buffeted the exposed hospital site (Bassett, 1992; Harris, 2011). In the winter of 1917, snow came through the tents and covered the patients in their beds in Salonica, and in France, the top blankets on patient beds would be stiff with ice each morning (Harris, 2011).

Likewise, for contemporary nurses, conditions were also often challenging and beyond what one would consider comfortable or "normal", particularly when deployed on humanitarian operations. In the tropical heat of Bougainville in 1997, everyone struggled: “working and living in confined conditions in sustained high temperatures without many of life's comforts that most of us take for granted, exposes the humanness in all of us on occasion" (Van Heemst \& Fisher, 2010: p. 336). Similarly in Banda Aceh in 2005, operating theatres were rapidly established under canvas in the throes of an oppressive tropical summer because there was no other permanent infrastructure available that provided protection 
from the heat (Christie, Taggart, \& Osborn, 2010), and the sight of the growing pile of dead bodies became normal and inconsequential (Krohn \& Almond, 2010). The nature of humanitarian operations means that often, much of the infrastructure in the region has been lost or destroyed, and as such, conditions were very primitive. Basic amenities such as electricity was generally not available, nor was plumbing or fresh water (Blundell, 2010; Christie, Taggart, \& Osborn, 2010; Clifford, Hem, \& Devlin, 2010; Oliver, 2010; Siers, 2013). Likewise, in East Timor in 2003, medical facilities were often quite primitive, with the largest 'threats' coming from the wildlife: "It was not unusual for pigs and other animals to be on the grounds and in the wards. [We] had to pig proof the clinic with some improvised fencing and self-closing gates" (Menzies, 2007: p. 67).

\subsection{Making a Difference}

Caring for one's own force is both a curse and a blessing. The nurse intrinsically wants to do everything they possibly can to nurse the soldier back to full healthto make a difference, but the kinds of injuries sustained in war mean that this is simply not always the case. Upon witnessing the death of a soldier who could not be resuscitated in Iraq in 2003, one nurse remembered: "I found myself in tears, mourning a soldier I had never met, not understanding why these young men and women were dying" (Robilliard, 2010: p. 411). In many futile cases in WW1, the best that the nurses could do was to help the wounded soldiers die decently (Rae, 2004), and in this way, that made a difference to the soldier. In Afghanistan, the nursing staff working in a large multinational medical unit found that caring for their own was difficult, especially because the "injuries sustained and managed in the ICU... were generally akin to the worst trauma patients seen in Australia... neurological trauma (primarily penetrating), massive blood transfusion, ...severe extremity injury, and coagulopathy associated with trauma" (Bell, 2014: p. 23). He further suggested that he was compelled to provide [our] service men and women with the best possible care because they deserved it for putting everything on the line. Knowing that their presence was a sense of comfort for soldiers should they become sick or injured served as motivation for nurses involved in the first Gulf War (Kumnick, Masotti, \& Taylor, 2010), highlighting a similar sentiment to that expressed during World War 1 (Bassett, 1992; Harris, 2011).

Governed by their professional code of conduct and the Geneva Convention, military nurses understand that they need to provide care to all humanity, irrespective of which "side" the patient was on. That is not to say that all nurses willingly accepted caring for prisoners of war and didn't resent their time being spent on enemy when "their own" needed their nursing care too (Harris, 2011), but the vast majority of nurses in both eras believed who their patient fought for was irrelevant when it came to providing quality nursing care (Rees, 2008; Robilliard, 2010; Steer, 2010; Siers, 2013). Robertson (2001) courageously suggested that when it came to resuscitation, she would rather have an enemy in the resuscitation bay than one of the Australian soldiers because it meant that the Aus- 
tralian soldiers survived the fight. This sentiment was shared by nurses in WW1: "If we had been nursing strange troops we may have felt it less, but among our own people the horrors of war are brought home to one more intensely" (Rees, 2008: p. 46).

However, military nurses do not just nurse those in uniform. During WW1, nurses involved in the consequences of the fighting on the Western Front frequently found themselves surrounded by displaced French civilians of all ages who required medical attention, stretching finite resources even thinner (Rae, 2006). Caring for local nationals is frequently an emotional and challenging experience, particularly when confronted with injuries and illnesses in children (Christie, Taggart, \& Osborn, 2010; Cook \& Werda, 2010; Durant, Wilkin, \& Peadon, 2010; Peadon, 1995, Robilliard, 2010; Werda, 1993). A normal aspect of humanitarian operations is caring for women and infants (Bayliss \& Wecker, 2010; Finucaine, 2010; Oliver, 2010; Wecker, 1993), a challenge for those military nurses with little to no midwifery or pediatric experience (Smith, DurantLaw, Oliver, \& Neumann, 2010). Humanitarian operations also allows nurses to work with health care workers native to the affected nation, which was described as extremely humbling (Hem, 2001), important (Rae \& Murphy, 2010), and satisfying (Oliver, 2010).

\subsection{Caught in the Crossfire}

The very environment in which military medical facilities are located often place them in the line of danger. Under the first Geneva Convention of 1864, a red cross (or red crescent) was selected as a symbol to be used to signify a hospital or health facility or worn to signify a medical person on a battlefield, which is theoretically meant to protect the facility and those that wear and work under the symbol as a neutral entity: hors de combat, or not part of the fight. However, in both eras, we have seen that the presence of a red cross does not always guarantee safety from enemy attack. For the WW1 nurses, the proximity of the CCS to the front line meant that they were regularly strafed by enemy fire. In fact, whilst temporarily assigned to a CCS in the battlefields of France in 1917, seven AANS nurses were decorated with the Military Medal for their "devotion to duty under fire" (Rae, 2006). Hospital ships off the coast of Gallipoli were shelled during that campaign (Rae, 2004). During the campaign in Passchendaele in late-1917, one casualty clearing station was in the path of a German advance, and was very close to being overrun, which would have seen the nurses either killed or taken prisoner of war (Barker, 1989).

In the context of the contemporary military operating environment, there is no longer a front line; indeed there is no line and the medical facilities are generally co-located with combat and combat support troops. This places nursing and medical staff in the warzone and all that this entails. Landmines were a real threat to the Australian nurses in Kurdistan in 1991, as the minefields were not mapped (Bayliss \& Wecker, 2010). In 1993, a nurse serving in Cambodia found herself looking down the barrel of an AK-47 held by an armed bandit who had 
just been caught stealing from the Australians (Hinchcliffe \& McLeod, 2010). In Bougainville in 1999, a nurse was held hostage in a local health clinic by an armed, psychotic local national (Duff \& Ginman, 2010). One of the biggest fears for nurses in Iraq during second Gulf War was mortars, frequently fired at the hospital and its surrounding base (Robilliard, 2010), as well as explosives and weapons smuggled in to the hospital by wounded to conduct a surprise attack from the inside (Sullivan, 2010). Similarly, nurses serving in Afghanistan were also rocketed by incoming mortars and faced the risk of improvised explosive devices (IED) when moving about on patrols. Even the layout of the bases serves to remind all that they are in a hostile environment: "with strong points guarding each corner and wire mesh acting as rocket and... bomb protection, it provides a... scary insight as to what we may face in the event of violence erupting again" (Alexander, 2002: p. 20). As a mode of rapidly transporting sick and wounded soldiers from the battlefield to medical facilities, helicopters are a tremendous resource. However, they are also exposed to enemy fire, and examples of nurses killed or wounded in crashed or downed helicopters have occurred throughout contemporary operations (Australian War Memorial, 2014a, 2014b; Hinchcliffe \& McLeod, 2010; Siers, 2013).

\subsection{Kinship and Military Family}

The enduring comradeship that blooms in the military is extraordinarily unique and tight. In fact, anyone who has not experienced military service would struggle to appreciate the depth of friendship that comes in sharing hardships and experiences whilst serving one's country. Goodman (1988) suggested that as nurses went through campaign after campaign together, many formed the kind of friendship that would last forever. An example of comradeship was exhibited between the nurses stationed in the more comfortable Egypt and those in the primitive and devastated Salonica, Greece, in 1917: "[I] did not send gifts home at Christmas in 1917 because the nurses in Egypt were sending parcels of groceries to the girls in Salonica because they are much worse off than we are" (Rae, 2004). A nursing officer commented that in Iraq during the second Gulf War that "mateship was the glue that held us all together. Without the constant care for colleagues and the mateship that resulted, our time in Iraq would have been long and tedious" (Steer, 2010: p. 404). Correspondingly, Hem (2001) advised that the hard work and arduous conditions brought her team in East Timor closer.

\subsection{Homecoming and Adjustments}

Returning home from overseas military service is unquestionably difficult for most. In most cases, the nurses involved in WW1 continued their work right up until they arrived in Australia, nursing returning soldiers on the ships bringing them home. This gave them a chance to gradually unwind and find a more "normal" rhythm away from a threat force. One nurse returning from a humanitarian operation in Cambodia in early 1993 noted that the deployment 
changed her: "I was quite restless and found my perspective had altered. For a while, my tolerance was low, especially concerning the seemingly petty things that others complained about" (Blundell, 2010: p. 277). For others, the experience added to their professional lives in unmeasured ways. On return from Rwanda in 1995, one nurse noted that she "went to Rwanda naïve and returned to Australia empowered and educated” (Owttrim, 2010: p. 302). Arguably, one of the more commonly held thoughts of nurses from both eras during their homecoming centered on the futility of war and man's inhumanity to man. Not everyone can be saved, and that is terribly hard for a nurse to live with (Rees, 2008; Robilliard, 2010; Sullivan, 2010). For those who participated in humanitarian operations, walking away knowing that there were still people who needed medical help was extremely difficult, described by Wright (2010, p. 297) as a sense of being "haunted by a sense of hopelessness in terms of what we left behind", but grateful for being able to help the few that they did (Finucaine, 2010; Irvine, Sargeant, \& Wade, 2010; Todd, 2010). For those involved in combat operations, there were always great concerns for those who had gone home completely changed by the war through injury (O’Malley, 2014), but a sense of pride in serving their country (Sullivan, 2010), just as their nursing ancestors had once done.

\section{Conclusion}

Whilst technology and medical innovation have led to significant changes in the way in which military medicine and nursing is conducted, and contemporary military nurses would be unrecognizable from the "grey and scarlet" days of last century with starched white cuffs and veils, at the heart of it, perhaps not much has changed. The blood that ran through the veins of our nursing ancestors is the same blood that runs through the veins of the 600-plus contemporary military nurses. It's still about "hooking in" despite unfamiliar, inhospitable, and often hostile surroundings. It is still about leadership, initiative, and innovation. It will always be about compassionate and sensitive care of humanity. The ghosts of our nursing ancestors do continue to walk amongst us, and if we stop to listen, we can hear their voices guiding our practice now and into the future.

\section{References}

Alexander, W. (2002). Pioneers in East Timor. Grey \& Scarlet, 2002, 18-22.

Ashley, D. (2013). Army's Spirit. Australian Army Journal, 10, 203-212.

Ashley, J. (2003). Mental Health Nurse Practitioner in the Australian Defence Force. Paper Presented at the 4th International Conference for Emergency Nurses, Sydney. Hobart, Australia: College of Emergency Nursing Australasia.

Australian War Memorial (2014a). Military Nursing Today. https://www.awm.gov.au/exhibitions/nurses/today/

Australian War Memorial (2014b). Roll of Honour. http://www.awm.gov.au/people/rolls/R1729485/

Barker, M. (1989). Nightingales in the Mud: The Digger Sisters of the Great War 1914-1918. Sydney: Allen \& Unwin. 
Bassett, J. (1992). Guns and Brooches: Australian Army Nursing from the Boer War to the Gulf War. Melbourne: Oxford University Press.

Bayliss, K., \& Wecker, G. (2010). My Kurdistan Experience. In C. McCullagh (Ed.). Willingly into the Fray: One Hundred Years of Australian Army Nursing (pp. 247-256). Newport: Big Sky Publishing.

Bell, P. (2014). NATO Multinational Medical Unit Role 3 ICU July-December 2013. Grey \& Scarlet, 2014, 23-24.

Biedermann, N. (2004). Tears on My Pillow: Australian Nurses in Vietnam. Milsons Point: Random House.

Biedermann, N. E. Usher, K., Williams, A., \& Hayes, B. A. (2001). The Wartime Experiences of Australian Army Nurses in Vietnam, 1967-1971. Journal of Advanced Nursing, 35, 543-549. https://doi.org/10.1046/j.1365-2648.2001.01870.x

Blundell, A. (2010). The Face of Cambodia. In C. McCullagh (Ed.), Willingly into the Fray: One Hundred Years of Australian Army Nursing (pp. 272-277). Newport: Big Sky Publishing.

Butler, J. (2006). Journey into War: A Woman's Diary. Australian Historical Studies, 127, 203-217. https://doi.org/10.1080/10314610608601211

Christie, E., Taggart, S., \& Osborn, K. (2010). Banda Aceh Experience. In C. McCullagh (Ed.), Willingly into the Fray: One Hundred Years of Australian Army Nursing (pp. 430-443). Newport: Big Sky Publishing.

Clifford, K., Hem, J., \& Devlin, A. (2010). Recollections of East Timor. In C. McCullagh (Ed.), Willingly into the Fray: One Hundred Years of Australian Army Nursing (pp. 375-385). Newport: Big Sky Publishing.

Cook, J., \& Werda, D. (2010). The Challenge that is Somalia. In C. McCullagh (Ed.), Willingly into the Fray: One Hundred Years of Australian Army Nursing (pp. 280-288). Newport: Big Sky Publishing.

Duff, N., \& Ginman, K. (2010). A Good Gut Feeling. In C. McCullagh (Ed.), Willingly into the Fray: One Hundred Years of Australian Army Nursing (pp. 345-351). Newport: Big Sky Publishing.

Durant, P., Wilkin, R., \& Peadon, R. (2010). Surgery with My Steyr at My Side. In C. McCullagh (Ed.), Willingly into the Fray: One Hundred Years of Australian Army Nursing (pp. 308-322). Newport: Big Sky Publishing.

Finucaine, J. (2010). Touching the Spirit. In C. McCullagh (Ed.), Willingly into the Fray: One Hundred Years of Australian Army Nursing (pp. 352-353). Newport: Big Sky Publishing.

Fleming, R. (2010). Forgotten Women of the Forgotten War: Australian Nurses in the Korean War, 1950-1956. Unpublished Doctoral Dissertation, Armidale: University of New England.

Fletcher, A. (2011). Sisters behind the Wire: Reappraising Australian Military Nursing and Internment in the Pacific during World War II. Medical History, 55, 419-424. https://doi.org/10.1017/S0025727300005500

Goodman, R. (1988). Our War Nurses: The History of the Royal Australian Army Nursing Corps 1902-1988. Brisbane: Booralong Publications.

Harding, J. (2010). In the Service of Peace. In C. McCullagh (Ed.), Willingly into the Fray: One Hundred Years of Australian Army Nursing (pp. 323-329). Newport: Big Sky Publishing.

Harris, K. (2008). "Rubbery Figures": The Puzzle of the Number of AANS on Active Service in WW1. Sabretache, 49, 5-10. 
Harris, K. (2009a). Red Reflections on the Sea: Australian Army Nurses Serving at Sea in World War 1. The Journal of Australian Naval History, 6, 51-73.

Harris, K. (2009b). Work, Work, Work: Australian Army Nurses after the First World War. In M. Crotty (Ed.), Proceedings of the When the Soldiers Return: November 2007 Conference (pp. 183-193). Brisbane: University of Queensland.

Harris, K. (2011). More than Bombs and Bandages: Australian Army Nurses at Work in World War 1. Newport: Big Sky Publishing.

Harris, K. (2013). “Giving the Dope”: Australian Army Nurse Anaesthetists during World War 1. Journal of Military and Veterans Health, 21, 45-50.

Harris, K. (2014). New Horizons: Australian Nurses at Work in World War 1. Endeavour, 38, 111-121.

Hem, J. (2001). Mid Life Crisis. Grey \& Scarlet, 2001, 57-60.

Hinchcliffe, N., \& McLeod, L. (2010). Bandits in Battambang. In C. McCullagh (Ed.), Willingly into the Fray: One Hundred Years of Australian Army Nursing (pp. 259-271). Newport: Big Sky Publishing.

Irvine, N., Sargeant, L., \& Wade, D. (2010). Bel Isi on Bougainville. In C. McCullagh (Ed.), Willingly into the Fray: One Hundred Years of Australian Army Nursing (pp. 337-344). Newport: Big Sky Publishing.

Krohn, P., \& Almond, K. (2010). Unspeakable Devastation. In C. McCullagh (Ed.), Willingly into the Fray: One Hundred Years of Australian Army Nursing (pp. 422-429). Newport: Big Sky Publishing.

Kumnick, D., Masotti, N., \& Taylor, W. (2010). A Sense of Comfort. In C. McCullagh (Ed.), Willingly into the Fray: One Hundred Years of Australian Army Nursing (pp. 235-246). Newport: Big Sky Publishing.

McCullagh, C. (2010). Willingly into the Fray: One Hundred Years of Australian Army Nursing. Newport: Big Sky Publishing.

Menzies, R. (2007). Timore Leste Nursing. Grey \& Scarlet, 2003-2007, 67-68.

O’Malley, B. (2014). My Deployment to the Role 3 MMU, Kandahar Afghanistan, July-December 2013. Grey \& Scarlet, 2014, 19-22.

O’Neill, D., \& Luther, M. (2013). Nurse Practitioner Led Health Facility (Role 1) on Exercise Precision Support, 2011: A Nurse Practitioner's Observational Report. Journal of Military and Veteran's Health, 21, 21-26.

Oliver, V. (2010). Paying Homage to the Goddess of Mercy. In C. McCullagh (Ed.), Willingly into the Fray: One Hundred Years of Australian Army Nursing (pp. 444-452). Newport: Big Sky Publishing.

Owttrim, A. (2010). Intensive Care Nursing Rwanda Style. In C. McCullagh (Ed.), Willingly into the Fray: One Hundred Years of Australian Army Nursing (pp. 298-302). Newport: Big Sky Publishing.

Peadon, R. (1995). Bandaid Medicine: One Australian Army Nurse's Experience in Rwanda. Grey \& Scarlet, 1995, 73-75.

Rae, L., \& Murphy, H. (2010). Dili Days. In C. McCullagh (Ed.), Willingly into the Fray: One Hundred Years of Australian Army Nursing (pp. 386-397). Newport: Big Sky Publishing.

Rae, R. (2004). Scarlet Poppies: The Army Experience of Australian Nurses during World War One. Burwood: The College of Nursing.

Rae, R. (2006). Ellen Julia Gould: A Civilian Nurse and Founder of the Military Nursing Tradition in Australia (1860-1941). Journal of the Royal Australian Historical Society, 
92, 165-182.

Rees, P. (2008). The Other ANZACS: Nurses at War 1914-1918. Crows Nest: Allen \& Unwin.

Robertson, M. (2001). Seeing through My Eyes: A Journal Entry from Operation Tanager, East Timor. Grey \& Scarlet, 2001, 63.

Robilliard, D. (2010). Tears for an Unknown Soldier. In C. McCullagh (Ed.), Willingly into the Fray: One Hundred Years of Australian Army Nursing (pp. 405-412). Newport: Big Sky Publishing.

Siers, R. (2013). Devotion: Stories of Australia's Wartime Nurses. Canberra: Department of Veterans' Affairs.

Smith, V., Durant-Law, P., Oliver, V., \& Neumann, S. (2010). Beyond the Dili Dustbowl. In C. McCullagh (Ed.), Willingly into the Fray: One Hundred Years of Australian Army Nursing (pp. 356-372). Newport: Big Sky Publishing.

Steer, G. (2010). Caring Despite the Circumstances. In C. McCullagh (Ed.), Willingly into the Fray: One Hundred Years of Australian Army Nursing (pp. 401-404). Newport: Big Sky Publishing.

Sullivan, K. (2010). Reflections: The People and the Memories. In C. McCullagh (Ed.), Willingly into the Fray: One Hundred Years of Australian Army Nursing (pp. 413-417). Newport: Big Sky Publishing.

Todd, L. (2010). Rwanda: Gods and Ghosts. In C. McCullagh (Ed.), Willingly into the Fray: One Hundred Years of Australian Army Nursing (pp. 303-307). Newport: Big Sky Publishing.

Van Heemst, E., \& Fisher, C. (2010). Smiling at the Outsiders. In C. McCullagh (Ed.), Willingly into the Fray: One Hundred Years of Australian Army Nursing (pp. 332-336). Newport: Big Sky Publishing.

Wecker, G. (1993). Op Habitat. Grey \& Scarlet, 1992-1993, 57-63.

Werda, D. R. (1993). Operation Solace, Somalia. Grey \& Scarlet, 1992-1993, 65-69.

Wright, B. (2002a). Humanitarian Aspects of Health Support in Operations Other than War. Seminars in Perioperative Nursing, 10, 121-125.

Wright, B. (2002b). The Role of the Military Nurse Practitioner in the ADF in the Provision of Health Support to Operations. Grey \& Scarlet, 2002, 11-17.

Wright, B. (2010). Out of Africa. In C. McCullagh (Ed.), Willingly into the Fray: One Hundred Years of Australian Army Nursing (pp. 291-297). Newport: Big Sky Publishing. 
Submit or recommend next manuscript to SCIRP and we will provide best service for you:

Accepting pre-submission inquiries through Email, Facebook, LinkedIn, Twitter, etc. A wide selection of journals (inclusive of 9 subjects, more than 200 journals)

Providing 24-hour high-quality service

User-friendly online submission system

Fair and swift peer-review system

Efficient typesetting and proofreading procedure

Display of the result of downloads and visits, as well as the number of cited articles Maximum dissemination of your research work

Submit your manuscript at: http://papersubmission.scirp.org/

Or contact ahs@scirp.org 